RESEARCH ARTICLE

\section{Invasive Mammals} in the National Parks

\section{System of Argentina}

\author{
M. L. Merino ${ }^{1,2,4}$ \\ B. N. Carpinetti ${ }^{3}$ \\ A. M. Abba ${ }^{1}$
}

${ }^{1}$ División Zoología Vertebrados

Museo de La Plata

Paseo del Bosque

s/n (B1900FWA)

La Plata, Argentina

2 Comisión de Investigaciones Científicas Provincia de Buenos Aires

3 Administración de Parques Nacionales Santa Fe 690

Ciudad Autónoma de Buenos Aires, Argentina

\footnotetext{
${ }^{4}$ Corresponding author:

mlmerino@fcnym.unlp.edu.ar
}

Natural Areas Journal 29:42-49

ABSTRACT: The National Parks System of Argentina (NPSA) comprises 33 protected areas $(3,546,044$ ha) and represents $1.25 \%$ of the country's total area. The goal of this work is to provide the first description of the distribution of invasive mammal species within the NPSA based on various information sources in order to assist future decision making concerning management strategies for these species. The occurrence of invasive mammals in different areas of the NPSA was determined from diverse sources: internal reports, mammal collections, survey questionnaires, and literature review. Sixteen invasive species are established within 26 of the $33(78.7 \%)$ protected areas of NPSA. The most widespread species is European hare (Lepus europaeus Linnaeus), followed by wild boar (Sus scrofa Linnaeus). Highest relative invasion indices are recorded in areas within the Patagonian forest, followed by areas in the Patagonian steppe. Two clearly different situations are present in the protected areas of the NPSA: (1) areas situated within the southern ecoregions, where invasive species have mostly been introduced for big game hunting purposes or fur farming, and (2) areas situated within the northern ecoregions, where the dominant invaders are feral species linked to cattle farming activities.

Index terms: alien species, conservation, ecoregion, Lepus europaeus, management, protected area, Sus scrofa, South America

\section{INTRODUCTION}

The National Parks System of Argentina (NPSA) consists of 33 protected areas (National Parks [-NP-], Natural Monuments [-NM-] and Reserves [-NR-]) comprising $3,546,044$ ha and representing $1.25 \%$ of the total surface area of the country. Most of the ecoregions that occur in Argentina are represented within the NPSA, with the exception of the Mesopotamian savanna and Pampa (Dinerstein et al. 1995; Burkart et al. 1999) (Figure 1). The creation of the system dates back to 1904, and Argentina was the third country in the world to formalize a national parks system. The creation of the first national parks (Nahuel Huapi and Iguazú) was the initial step of the implementation of conservation efforts on the part of the Argentinean government.

The mammalian fauna of Argentina includes 320 native terrestrial species, 77 of which are endemic, whereas 31 exotic species have been recorded to date (Navas 1987; Bonino 1995; Ojeda et al. 2002). Most exotic species were intentionally introduced for different purposes (e.g., economic exploitation, big game hunting, alternative resources), with the exception of the murid genera Rattus and Mus (Navas 1987). The last successful introduction of a mammal (American beaver (Castor canadensis Kuhl), and muskrat (Ondatra zibethicus Linnaeus)) in Argentina occurred > 30 years ago (Navas 1987; Bonino 1995).

At least nine exotic species are restricted to hunt preserves; these include the white-tailed deer (Odocoileus virginianus Zimmermann), red deer or wapiti (Cervus elaphus canadensis Erxleben), Pére David's deer (Elaphurus davidianus Milne-Edwards), Himalaya thar (Hemitragus jemlahicus C.H. Smith), barbary sheep (Ammotragus lervia Pallas), wisent (Bison bonasus Linnaeus), chamois (Rupicabra rupicapra Linnaeus), mouflon (Ovis aries musimon Pallas), and ibex (Capra ibex Linnaeus) (Navas 1987; Bonino 1995).

Horses (Equus caballus Linnaeus) and cows (Bos taurus Linnaeus) rapidly became feral after being first introduced during the early stages of Spanish colonization in 1536 and 1549 respectively (Romero Aguirre 1957; Sal Paz 1986). There is a well established population of goats (Capra hircus Linnaeus) in Isla de los Estados, Tierra del Fuego province (Navas 1987; Massoia and Chebez 1993). Feral pigs (Sus scrofa Linnaeus) have been established since 1741 (Iriart 1997), occupying the southern coastal area of Río de La Plata north to Mar Chiquita saltwater lagoon and possibly to the coast of Necochea County (Merino and Carpinetti 2003). Feral donkeys (Equus asinus Linnaeus) were introduced around 1550 in northwestern Argentina as pack animals for mining activities (Giberti 1985). Feral cats (Felis cattus Linnaeus) and dogs (Canis familiaris Linnaeus) are the most destructive species (Dickman 1996), and are often mentioned; only rarely do they form stable populations. 


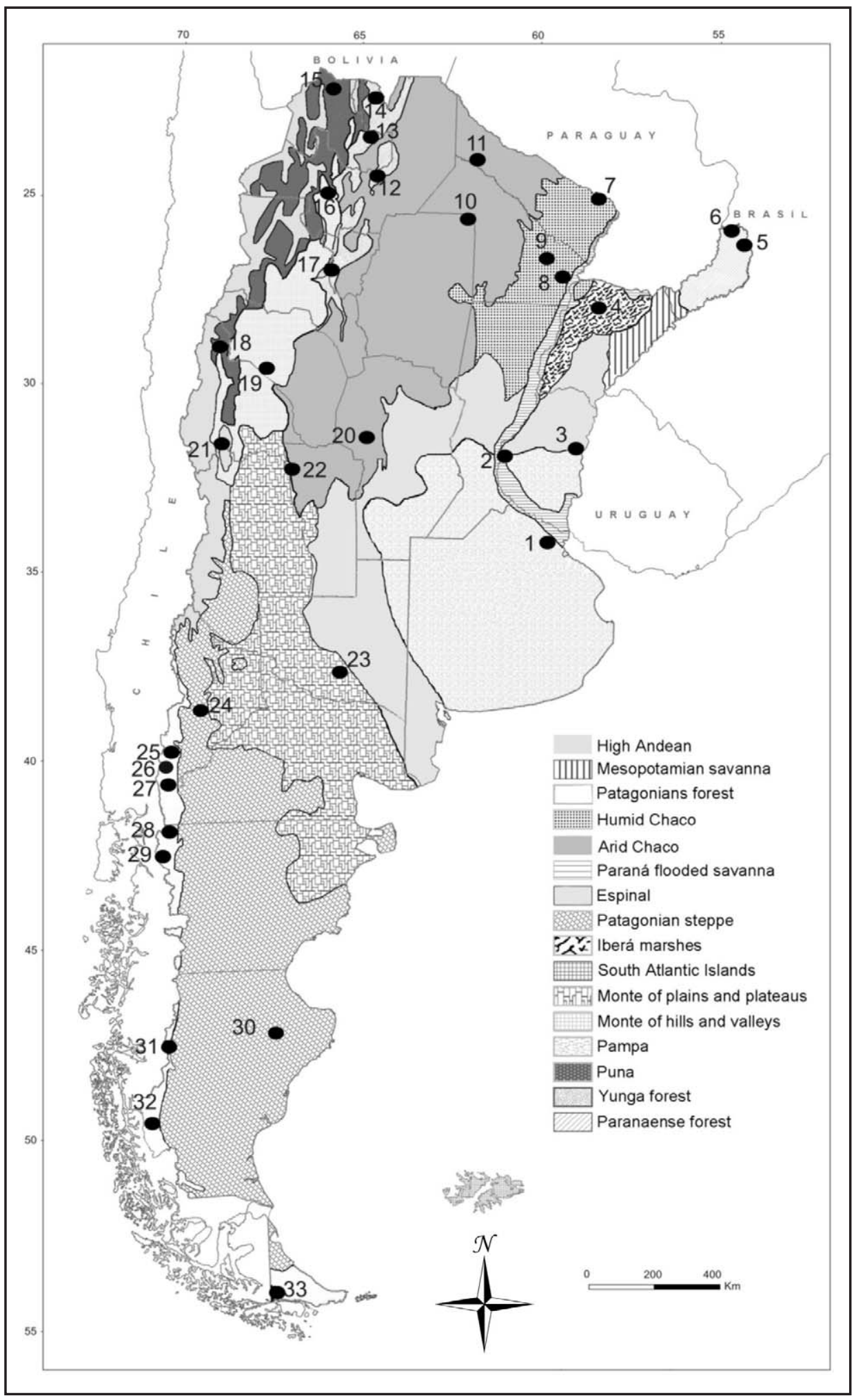

Figure 1. Protected Areas of the National Parks System of Argentina. (1) Otamendi NR; (2) Pre-Delta NP; (3) El Palmar NP; (4) Mburucuyá NP; (5) San Antonio NR; (6) Iguazú NP; (7); Río Pilcomayo NP; (8) Colonia Benitez NR; (9) Chaco NP; (10) Copo NP; (11) Formosa NP; (12) El Rey NP; (13) Calilegua NP; (14) Baritú NP; (15); Laguna de Pozuelos NP; (16) Los Cardones NP; (17) Campo de los Alisos NP; (18) San Guillermo NP; (19) Talampaya NP; (20) Quebrada del Condorito NP; (21) El Leoncito NP; (22) Sierra de las Quijadas; (23) Lihue-Calel NP; (24) Laguna Blanca NP; (25) Lanín NP; (26) Nahuel Huapí NP; (27) Los Arrayanes NP; (28) Lago Puelo NP; (29) Los Alerces NP; (30) Bosques Petrificados NR; (31) Perito Moreno NP; (32) Los Glaciares NP; (33) Tierra del Fuego NP.
No data on population status are available for several introduced species, including the reindeer (Rangifer tarandus Hamilton Smith) and silver fox (Vulpes vulpes Linnaeus) in Tierra del Fuego island (Massoia and Chebez 1993), the mule deer (Odocoileus hemionus Rafinesque) in the Ambato (Catamarca) and Aconquija (Tucumán) mountains, and the African buffalo (Syncerus caffer Sparrman) in Corrientes province (Navas 1987).

The only mammals that were unintentionally introduced are the three murid species that arrived in colonist European ships. Populations of black rats (Rattus rattus Linnaeus) and house mice (Mus domesticus Schwarz and Schwarz) have been established possibly since the foundation of Buenos Aires city in 1536. Later they began to spread along with urban settlements in the northeastern Pampas region. Norway rats (Rattus norvegicus Berkenhout) are presumed to have entered the country during the last decades of the 18th century (Coto 1997).

Nineteen of these 31 introduced mammal species are considered invasive, according to the definition of "invasive exotic species" as those exotic species that occur in natural or semi-natural ecosystems or habitats, are agents of change, and threaten the native biological diversity (SSC-Invasive Species Specialist Group 2001).

The issue of invasive mammals is poorly understood in Argentina, and comprehensive publications about the distribution and impacts of these species are scarce (Navas 1987; Jackson 1988; Massoia and Chebez 1993; Chebez 1994), although some have been published that focus on particular species, mostly in reference to Argentinean Patagonia (Daciuk 1978; Grigera and Rappoport 1983; Pagnoni et al. 1986; Veblen et al. 1989; 1992; Lizarralde 1993; Bonino 1995; Flueck et al. 1995; Lizarralde et al. 1996; Aued et al. 2003). Some specific works that referred to the ecoregions Pampa (Recarey 1990; Aprile and Chicco 1999; Carpinetti and Merino 2000; Merino and Carpinetti 2003) and Yunga Forest (Grau et al. 1995) have also been published. 
Our poor understanding of the distribution and ecology of invasive mammal species and their effects on ecosystems limits the development of management programs. Consequently, summarizing current information on the geographical distribution of these species within the NPSA is vital, and represents a fundamental tool for biodiversity conservation. Invasive species have been acknowledged as a serious conservation problem by the NPSA administrative agency, the National Parks Administration (APN 2001).

The goal of this work is to provide the first description of the distribution of invasive mammal species within the NPSA based on various information sources and to assist in future decision making concerning management strategies for these species.

\section{MATERIALS AND METHODS}

The occurrence of invasive mammal species in different areas of the NPSA was determined based on information obtained from diverse sources: (1) Most of the available information is included in internal reports of the different APN bureaus that regulate the management of protected areas. Consequently, we analyzed the Action and Operative Plans of each of the areas that form the national system. These plans contain information about the presence of these species and, in some cases, details of management activities undertaken with respect to invasive mammals; (2) We performed an exhaustive review of the major mammal collections of Argentina where material from NPSA is deposited: Museo Argentino de Ciencias Naturales "Bernandino Rivadavia" and Museo de La Plata; (3) To obtain current information on the occurrence of exotic species, we administered survey questionnaires to the individuals responsible for management policies in each of the protected areas. These questionnaires focused on determining the presence/absence of the invasive species; and (4) We performed a literature review for records of the presence of invasive mammal species within the NPSA (Daciuk 1978; Navas 1987; Jackson 1988; Lizarralde 1993; Massoia and Chebez 1993; Chebez 1994; Bonino
1995; Lizarralde et al. 1996; Heinonen Fortabat and Chebez 1997; Grigera 1999; Carpinetti and Merino 2000; Jaksic et al. 2002; Vazquez 2002; Acenolaza et al. 2004).

We obtained the relative invasion index (Macdonald et al. 1988) for each area of NPSA and ecoregion. This index is calculated as:

$$
\mathrm{V}=100 \mathrm{I} / \mathrm{S}
$$

where I is the number of invasive species and $S$ is the total number of species irrespective of whether they are invasive or native. The differences in relative invasion indices between each protected area (IRI) and the ecoregion where they are located (EIRI) were tested by means of a chi-square test. The ecoregional scheme follows Burkart et al. (1999) (Figure 1).

Similarity between areas of the SNAP was calculated based on presence or absence of species, using Jaccard's Coefficient (Krebs, 1999).

$$
\text { Jaccard's Coefficient }=\frac{a}{a+b+c}
$$

$\mathrm{a}=$ number of species present in both sample A and sample B

$\mathrm{b}=$ number of species present in sample B but not in sample A

$c=$ number of species present in sample A but not in sample B

The similarity matrix obtained from application of Jaccard's Coefficient was used to perform an analysis of association among areas within the NPSA through application of unweighted pair-group arithmetic averaging cluster algorithm (UPGMA).

Monte León National Park was incorporated to the NPSA in 2002 at a time when our analysis (2002-2003) had already started. Therefore, it was not included in this study.

\section{RESULTS}

Sixteen of the 31 exotic mammalian species present in Argentina occur within the NPSA: feral cat (Felis catus), American mink (Mustela vison Schreber), European hare (Lepus europaeus Linnaeus), European wild rabbit (Oryctolagus cuniculus Linnaeus), muskrat, Norway rat, black rat, American beaver, blackbuck antelope (Antilope cervicapra Linnaeus), axis deer (Axis axis Erxleben), domestic cattle, red deer (Cervus elaphus Linnaeus), fallow deer (Dama dama Linnaeus), wild boar (Sus scrofa Linnaeus), domestic ass (Equus asinus), and horse.

Invasive mammals occur in $78.7 \%(\mathrm{n}=26)$ of the protected areas that form the NPSA. No established populations of invasive species were detected in three areas in the Yunga Forest (Baritú NP, Calilegua NP, and Campo de Los Alisos NP), one area in the Puna (Laguna de Los Pozuelos NM), one in Arid Chaco (Copo PN), one in Humid Chaco (Colonia Benitez RN), and one in to the Paranensean Forest (San Antonio $\mathrm{RN})$. The most widespread species within the system is Lepus europaeus, which occurs in $63.6 \%$ of the NPSA where invasive mammals are present, followed by Sus scrofa which occurs in $21.3 \%$. In contrast, Ondatra zibethicus and Castor canadensis (Tierra del Fuego NP) as well as Antilope cervicapra (El Palmar NP) and Equus caballus (Bosques Petrificados NM) only occur in a single area of the system.

The highest relative invasion indices are recorded in areas situated within the Patagonians forest, which have a mean value of $18.8 \%$, followed by sites in the Patagonian steppe with $12.9 \%$ and Monte with $6.59 \%$. The lowest indexes are recorded in those areas situated in the subtropical forest (Yunga and Paranaense) with $3.16 \%$ and in Chaco with $3.27 \%$ (Humid and Arid) (Table 1).

The comparison of relative invasion indexes between NPSA protected areas and their respective ecoregions shows significant differences in the following areas: Perito Moreno NP $(x=16.47$, df $=1, \mathrm{P}<0.05)$ (Patagonian forest), Formosa RN ( $x=4.86$, $\mathrm{df}=1, \mathrm{P}<0.05)$ and Quebrada del Condorito NP $(x=6.97, \mathrm{df}=1, \mathrm{P}<0.05)$ (Arid Chaco), Sierra de las Quijadas $\mathrm{NP}(x=6.07, \mathrm{df}=1, \mathrm{P}<0.05)$ (Monte of plains and plateaus), El Leoncito NP $(x=36.9, \mathrm{df}=1, \mathrm{P}<0.05)$, and Talampaya 


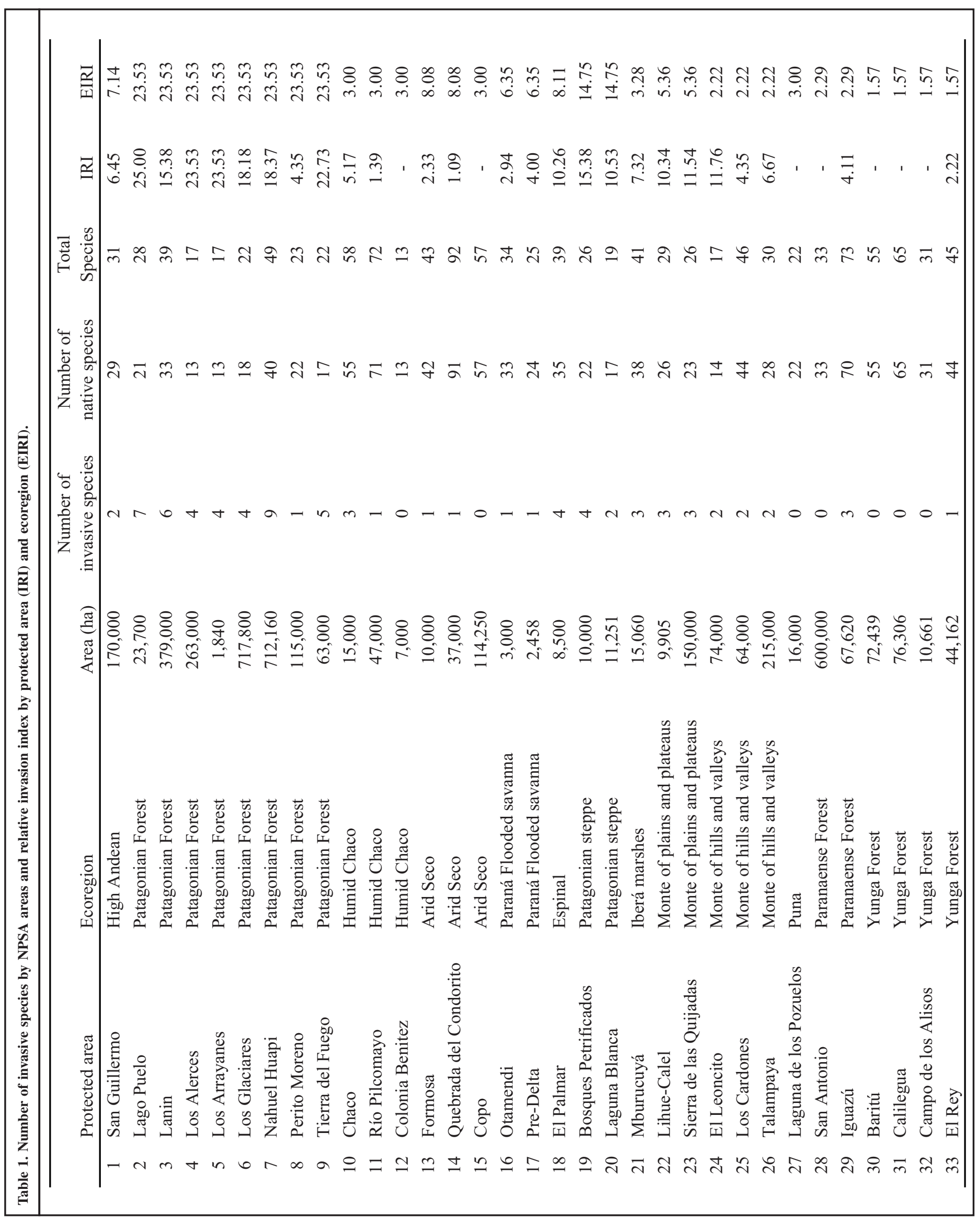


$\mathrm{NP}(x=7.11, \mathrm{df}=1, \mathrm{P}<0.05)$ (Monte of hills and valleys). In the first three areas, the invasion index is lower than that for the ecoregion, whereas in the last three areas, the index is higher. In the case of Perito Moreno NP, this area was considered as part of the ecoregion Patagonians forest, although this park includes also a sector of Patagonian steppe.

Seven clusters were obtained based on Jaccard's similarity coefficients (Figure 2). Cluster A, represented by Tierra del Fuego $\mathrm{NP}$, has four species of invasive mammals, including two exclusive invasive taxa, Castor canadensis and Ondatra zibethicus.

Cluster B includes most of the Patagonian forest areas along with El Palmar NP and Lihuel Calel NP; all these areas feature a high diversity of invasive species. The inclusion of EL Palmar NP within this cluster is due to the shared presence of Lepus europaeus and Sus scrofa. These two species are widely distributed in the three ecoregions comprised by this cluster (Espinal, Monte of plains and plateaus, and Patagonians forest).

Cluster $\mathrm{C}$ is formed by areas with low diversity of invasive species; the latter are generally represented by the most widespread species, Lepus europaeus. A second species, Oryctolagus cuniculus, is added in the case of Laguna Blanca NP.

Cluster D includes protected areas situated in arid zones, with low diversity of invasive species $(n<4)$. Within this assemblage, a smaller cluster is characterized by the presence of Equus asinus (Los Cardones NP, San Guillermo NP, and Talampaya NP).

Cluster E comprises two sub-clusters: El Rey NP - Pilcomayo NP, an area with a single invasive species, Bos taurus; and Mburucuya NP - Bosques Petrificados $\mathrm{NP}$, where this species is joined by Lepus europaeus.

Lastly, cluster F, formed by the Pre Delta NP protected area, is characterized by the presence of Axis axis only.

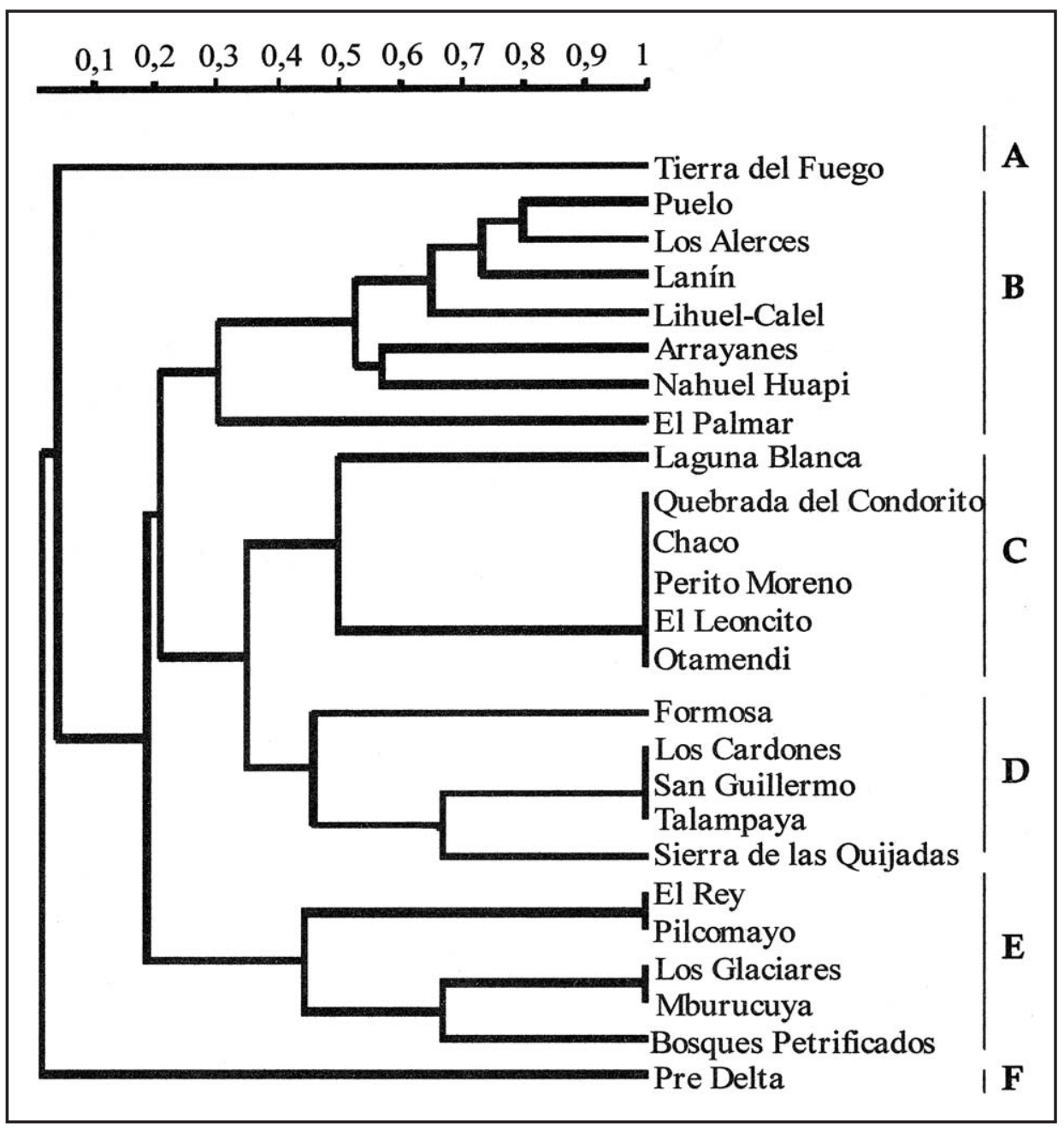

Figure 2. Phenograms of protected NPSA areas based upon UPGMA; clustering algorithm based on Jaccard's Index.

\section{DISCUSSION}

Biological invasions are particularly important in disturbed areas, where they are considered to be primarily consequences of disturbance rather than components of change in their own right (Vitousek et al. 1997). Protected areas are expected to be least disturbed; but in the case of the NPSA, the level of occurrence of invasive species is high, and almost $80 \%$ of the areas host $\geq 1$ species. Apart from this, there are no marked differences between NPSA areas and their encompassing ecoregions with respect to the presence of invasive species. This evidences a deficiency of controls on the part of the administrative agency both to prevent the entrance of these species and to control those that already occur within protected areas. Whence outside areas are reinvaded, this inefficient control of invasive species has led to many instances of the protected areas functioning as "reservoirs" for invasives. The population of Sus scrofa in El Palmar NP (Govetto 1999), or the beavers (Castor canadensis) in Tierra del Fuego NP (Lizarralde 1993; Lizarralde et al. 2004), are cases in point. Erratic management policies result in long periods during which no control measures are exerted; this situation, coupled with the population growth of these species, generates the invasion of bordering areas. Conversely, during those periods in which control measures are implemented, these adjacent areas act as dispersal centers toward the protected areas, thus generating a feedback loop that multiplies the costs of all implemented programs, both in terms of time and human resources required.

The low numbers of invasive species in 
seven areas could be explained by two possible factors: (1) the mammalian fauna of these areas has not been extensively surveyed (San Antonio RN, Colonia Benitez RN, and Laguna de Los Pozuelos NM) (Heinonen Fortabat and Chebez 1995), and (2) they are situated in ecoregions (Yungas Forest and Arid Chaco) with low relative invasion indexes $(<3)$.

Lepus europaeus, the most widespread species within the system $(60.5 \%)$, was introduced from Germany in 1888 for big game hunting purposes (Grigera and Rapoport 1983). Its high reproductive potential and adaptive capacity have allowed it to currently occupy almost the entire Argentinean territory, with the exception of Tierra del Fuego; these characteristics account for its status as the most widespread species within the NPSA. Lepus europaeus competes with livestock for pastures, and damages grasslands, crops, orchards, and forestry plantations (Bonino et al. 1986; Bonino 1995). On the other hand, Lepus europaeus is currently an important item in the diet of middle-sized and large predators, including native birds and mammals (Novaro et al. 2000; Donadío et al. 2001).

Sus scrofa is another widespread species in the system $(21.3 \%)$; it causes several environmental disturbances, primarily through rooting for herbs, subterranean tubers, and invertebrates. The activities of this species generate increasingly larger expanses of bare ground, intensifying erosive processes in mountainous areas as well as leaching and loss of nutrients from the forest floor and upper soil horizons, and also inhibit or delay the regeneration of woody plants (Bratton 1975; Singer et al. 1984). Sus scrofa does not have natural predators, and only big game hunting activities have some controlling effect on its populations. The fact that the two most widespread exotic species within the NPSA cause important environmental impacts should be an alarm sign for this system's administration agency.

One out of 10 introduced species establishes permanent populations, and of these, one in 10 becomes an invasive species (Williamson and Fitter 1996). This prob- ability-based rule is known as "rule of ten" and in those cases where it has been actually tested, real values range between $5 \%$ and $20 \%$ (Williamson 1999). In the case of the mammals introduced to Argentina, $61 \%$ of the species with recorded introductions have become invasive. This very high percentage could be due to the high proportion of ungulates $(50 \%)$ among the invasives introduced to the territory and especially within the NPSA. This group is particularly scarce both in South America (22 native species) and in Argentina (12 native species); and, consequently, these exotic ungulates are able to use underexploited resources, while at the same time encountering lower pressures from parasites, predators, and diseases.

An additional consideration is the fact that the first stage of a biological invasion consists of the colonization of new environments, which demands good dispersal abilities for the successful invader. In the case of ungulates, most of the species were introduced as cattle or as big game hunting resources and, consequently, their dispersal was directly favored by human activities. These included active transport of individuals with the consequent creation of new invasion foci. Studies about ecological effects of invasive ungulates in Argentina are scarce, with the exception of research that focused on the Patagonian forest (Veblen et al. 1989, 1992; Simberloff et al. 2003). However, ungulate species produce several negative ecological effects (including changes in soil structure and nutrient cycling that lead to enhanced erosion) as well as changes in plant species composition and cover that include dispersal of invasive plant species and consumption of endemic vegetation (Singer et al 1984; Mack and D’Antonio 1998; Vasquez 2002). In addition, these species act as vectors of endemic and exotic diseases and also of parasites that can affect other animals, including domestic livestock and humans. (Choquenot et al. 1996).

The present cluster analysis shows that two clearly different situations are present in the protected areas of the NPSA. In those areas situated within southern ecoregions (Patagonian forest, Patagonian steppe, and Monte of plains and plateaus), where invasive species were mostly introduced for big game hunting purposes (i.e., Cervus elaphus and Dama dama) or fur farming (Castor canadensis and Mustela vison), the first of these activities currently plays a major role in local economies, and hunt preserves situated within protected areas generate considerable income. This economic interest was the reason behind the support given in the past to the introduction of a great number of exotic species into protected areas within these ecoregions. The situation is different in the NPSA areas situated within northern ecoregions where the dominant invaders are feral species linked to cattle farming activities (Equus asinus and Bos taurus). This could be due to the fact that many of the protected areas were originally occupied by cattlebreeding farms, and some of the former are currently being invaded by cattle from adjoining farms.

Considering these two different situations within NPSA protected areas, it is possible to develop regional strategies for the management of mammal invasive species. Currently, the policy of the APN does not clearly emphasize the control of invasive mammal species, with the exception of some cases such as Sus scrofa in El Palmar NP or Bos taurus in El Rey NP. Indeed, an invasive species such as Cervus elaphus, which causes strong environmental impacts (Veblen et al. 1989, 1992), is managed as a sustainable resource and its hunting is under strict control. One factor behind this absence of continuous policies is the lack of interest on the part of the Argentinean mammalogist community in the study of basic aspects of the ecology of these species and their interaction with the ecosystems present in the diverse ecoregions for which the NPSA is the major conservation instrument. Fortunately, this trend shows signs of change, as demonstrated by the publication of works on these species during the last years (Merino and Carpinetti 2003; Simberloff et al. 2003; Bonino and Sorigue 2004; Guichón et al. 2005).

\section{ACKNOWLEDGMENTS}

We would like to especially thank all the staff at the National Parks Administration 
who completed the survey questionnaires: Roberto Cerda, Néstor Sucunza, Carlos Zoratti, Sergio Domber, Jorge Romero Dindorf, Cristóbal Paramosz, Miguel Ángel Dedek, Pedro D. Ramírez, Leo Montenegro, Carlos Duprez, Juan Sergio Bikauskas, Carlos Rabagliatti, Francisco Gallardo, Alejandro Carrizo, Jorge Blanco, Fernando Dobrotinich, Daniel Vega, Laura Malmierca, Antonio Temporetti, Víctor Arrechea, Carlos Corvalan, Silvia Chalukian and Salvador Vellido. We thank Mirta Garciarena for her help in the analysis of survey questionnaires.

Mariano L. Merino is a Researcher at Vertebrates Division of the Museum de La Plata. His professional interests include invasive mammal species and conservation of the neotropical deer.

Bruno N. Carpinetti is a Conservation Biologist for the Argentinean National Parks Service. His work involves several aspects of natural areas management. Currently his work focuses on Iguazu National Park's planning and management.

Agustin M. Abba is a researcher of Vertebrate Division of Facultad de Ciencias Naturales y Museo, Universidad Nacional de La Plata. His research focuses on mammalian biology, especially on xenarthrans ecology.

\section{LITERATURE CITED}

Aceñolaza, P.G., H.E. Povedano, A. Manzano, A. Muñoz, J. Areta, and A.J. Ronchi Virgolini. 2004. Biodiversidad del Parque Nacional Pre-Delta. Pp. 169-184 in F.G. Aceñolaza, ed., Temas de la Biodiversidad del Litoral Fluvial Argentino. Miscelánea 12 INSUGEO.

APN. 2001. Plan de Gestión Institucional para los Parques Nacionales. Administración de Parques Nacionales, Buenos Aires.

Aprile, G., and D. Chicco. 1999. Una especie de mamífero en la Argentina: la ardilla de vientre rojo (Callosciurus erythaeus). Mastozoología Neotropical 6:7-14

Aued, M.B., C. Chehebar, G. Porro, D.W. MacDonald, and M.H. Cassini. 2003. Environmental correlates of the distribution of southern river otters Lontra provocax at dif- ferent ecological scales. Oryx 37:413-421.

Bonino, N.A. 1995. Introduced mammals in Patagonia, southern Argentina: consequences, problems, and management considerations. Pp. 406-409 in J.A. Bissonette and P.R. Krausman, eds., Proceedings of the First International Wildlife Management Congress, The Wildlife Society, Bethesda.

Bonino, N., G. Bonvissuto, A. Pelliza Sbriller, and R. Somlo. 1986. Hábitos alimentarios de los herbívoros en la zona central del área ecológica Sierras y Mesetas occidentales de Patagonia. Revista Argentina de Produción Animal 6:275-287.

Bonino, N., and R.C. Sorigue. 2004. Distribución actual y dispersión del conejo europeo (Oryctolagus cuniculus) en Mendoza (Argentina). Mastozoología Neotropical 11:237-241.

Bratton, S.P. 1975. The Effect of the European Wild Boar, Sus scrofa, on Gray Beech Forest in the Great Smoky Mountains. Ecology 56:1356-1366.

Burkart, R., N.O. Bárbaro, R.O. Sánchez, and D.A. Gomez. 1999. Eco-regiones de la Argentina. Administración de Parques Nacionales, Buenos Aires.

Carpinetti B.N., and M.L. Merino. 2000. Distribution of chital Axis axis (Erxleben, 1777) in Buenos Aires Province, Argentina. Journal Bombay Natural History Society 97:271-272.

Chébez, J.C. 1994. La introducción de especies exóticas. Pp. 24-30 in J.C. Chebez, ed., Los que se van: especies Argentinas en Peligro. Editorial Albatros, Buenos Aires.

Choquenot, D., J. McIlroy, and T. Korn. 1996. Managing vertebrate pests: feral pigs. Bureau of Resource Science, Canberra.

Coto, H. 1997. Biología y control de ratas sinantrópicas. Editorial Abierta, Buenos Aires.

Daciuk, J. 1978. Estado actual de las especies de mamíferos introducidos en la Subregión Araucana (Republica Argentina) y grado de coacción ejercido en algunos ecosistemas surcordilleranos. Anales de Parques Nacionales 14:105-130.

Dickman, C.R. 1996. Overview of the impact of feral cats on Australian native fauna. Australian Nature Conservation Agency, Canberra.

Dinerstein E., D.M. Olson, D.J. Graham, A.L. Webster, S.A. Primm, M.P. Bookbinder, and G. Ledec. 1995. Conservation assessment of the terrestrial ecoregions of Latin America and the Caribbean. World Wildlife Fund, Washington, D.C.

Donadío, E., M. B. Bongiorno, M. Monteverde, G. Sánchez, M.C. Funes, O. Pailacura, and
A. Novaro. 2001. Ecología trófica del puma (Puma concolor), culpeo (Pseudalopex culpaeus), águila (Geranoaetus melanoleucus) y lechuza (Tyto alba) en Neuquén, Patagonia Argentina. Libro de Resúmenes I Reunión Binacional de Ecología Chilena-Argentino. Bariloche (Río Negro).

Flueck, W.T., J.M. Smith-Flueck, and K.A. Ruegg. 1995. Management of introduced red deer in Patagonia. Pp. 525-528 in J.A. Bissonette and P.R. Krausman, eds., Proceedings of the First International Wildlife Management Congress. The Wildlife Society, Bethesda, Md.

Giberti, H.C. 1985. Historia económica de la ganadería Argentina. Hyspamerica Ediciones, Buenos Aires.

Goveto, L.A. 1999. Manejo adaptativo de las poblaciones de jabalíes en las áreas protegidas. Dirección Nacional de Conservación de Áreas Protegidas, Administración de Parques Nacionales, Buenos Aires.

Grau, A., S. Halloy, E. Domínguez, J.A. Gonzalez, and R. Vides. 1995. Ciervos introducidos. Estudio de su impacto ambiental en el noroeste argentino. Fundación Miguel Lillo, Serie Conservación de la Naturaleza 10:1-13.

Grigera, D.E. 1999. Conocimiento y estado de conservación de la biodiversidad de vertebrados en la Patagonia Argentina. Gestion Ambiental 5:62-78.

Grigera, D.E., and E.H. Rappoport. 1983. Status and distribution of the European hare in South American. Journal of Mammalogy 64:163-166.

Guichón, M.L., M. Bello, and L. Fasola. 2005. Expansión poblacional de una especie introducida en la Argentina: la ardilla de vientre rojo Callosciurus erythraeus. Mastozoología Neotropical 12:189-197.

Heinonen Fortabat, S., and J.C. Chebez 1995. Los mamíferos del sistema de parques nacionales de la Argentina. Monografía Especial L.O.L.A. 14:1-70.

Heinonen Fortabat, S., and J.C. Chebez 1997. Los mamíferos de los Parques Nacionales de la Argentina. Monografía Especial Literature of Latin America, [Argentina].

Iriat, R. 1997. Evolución histórica de la pampa Deprimida. Pp. 351-368 in C.E. Berbeglia, ed., Propuesta para una Antropología Argentina IV. Editorial Biblos, Buenos Aires.

Jackson, J.E. 1988. Terrestrial mammalian pests in Argentina. An overview. Pp. 196-198 in A.C. Crab and R.E. Marsh, eds., Proceedings of Thirteenth Vertebrates pest Conference, University of California Press, Davis.

Jaksic, F.M., J.A. Iriarte, J.J.E. Jimenez, and D. Martinez. 2002. Invaders without frontiers: 
cross-border invasions of exotic mammals. Biological Invasions 4:157-173.

Krebs, J.C. 1999. Ecological Methodology. $2^{\text {nd }}$ ed. Addison-Wesley Educational Publishers, Menlo Park, Calif.

Lizarralde, M.S. 1993. Current status of the introduced Beaver (Castor canadensis) population in Tierra del Fuego, Argentina. Ambio 22:351-358.

Lizarralde, M.S., G.A. Deferrari, S.E. Alvarez, and J.M. Escobar. 1996. Effects of beaver (Castor canadensis) on the nutrient dynamics of the southern beech forest of Tierra del Fuego (Argentina). Ecología Austral 6:101-105.

Lizarralde M.S., J.M. Escobar, and G.A. Deferrari. 2004. Invader species of Argentina: a review about beaver (Castor canadensis) population situation on Tierra del Fuego ecosystem. Interciencia 29:352-356.

Macdonald, I.A.W., D.M. Graber, S. De Benedetti, R.H. Groves, and E.R. Fuentes. 1988. Introduced species in nature reserves in Mediterranean type climatic regions of the world. Biological Conservation 44:37-66.

Mack, M.C., and C.M. D’Antonio 1998. Impacts of biological invasions on disturbance regimes. Trends in Ecology and Evolution 13:195-198.

Massoia, E., and J.C. Chébez. 1993. Mamíferos Silvestres del Archipiélago Fueguino. L.O.L.A., Buenos Aires.

Merino, M.L., and B.N. Carpinetti. 2003. Feral pig Sus scrofa population estimates in Bahía Samborombón conservation area, Buenos Aires Province, Argentina. Mastozoología Neotropical 10:269-275.
Navas, J.A. 1987.Los vertebrados exóticos introducidos en la Argentina. Revista del Museo Argentino de Ciencias Naturales Serie Zoología 14:7-38.

Novaro A., Funes M. C., and S. Walker. 2000. Ecological extinction of native prey of a carnivore assemblage in Argentine Patagonia. Biological Conservation 92:25-33.

Ojeda, R.A., C.E. Borghi, and V.G. Roig. 2002. Mamíferos de Argentina. Pp. 23-64 in G. Cevallos and J. Simonetti, eds., Diversidad y Conservación de los Mamíferos Neotropicales. CONABIO - UNAM México.

Pagnoni, G.O., J.L. Garrido, and M.R. Marín. 1986. Impacto económico y ambiental del vison, Mustela vison (Schreber, 1877) en el norte de la Patagonia. CENPAT-CONICETDirección de Fauna Silvestre, Provincia de Chubut, Rawson.

Recarey, J.C. 1990. Un nuevo mamíferos exótico introducido en la Argentina. Sciurus vulgaris Linné, 1776 (Mammalia. Sciuridae) en el Partido de Lujan, Provincia de Buenos Aires. Comunicaciones del Centro de Investigaciones Francisco Javier Muñiz 1:1-3.

Romero Aguirre, M.A. 1957. Ganadería Argentina, su desarrollo e industrialización. Compañía Swift de la Plata S.A.

Sal Paz, F.P. 1986. El bovino criollo argentino: historia, características y productividad. Pp. 3-7 in Subcomité Asesor del Árido Subtropical Argentino de la Secretaria de ciencia y Técnica, ed., Orientación Gráfica Editora SRL, Buenos Aires.

Simberloff, D., M.A. Relva, and M. Nuñez. 2003. Introduced Species and Management of a Nothofagus/Austrocedrus Forest. Environmental Management 31:263-275.
Singer, F.J., W.T. Swank, and W.T. Clebsch. 1984. Effects of wild pig rooting in a deciduous forest. Journal of Wildlife Management 48:464-473.

SSC - Invasive Species Specialist Group. 2001. IUCN Guidelines for the prevention of biodiversity loss caused by alien invasive species. Available online <http://www.iucn. org/themes/ssc/pubs/policy/invasivesEng. htm>

Vázquez, D.P. 2002. Multiple effects of introduced mammalian herbivores in a temperate forest. Biological Invasions 4:175-191.

Veblen, T.T., M. Mermoz, C. Martin, and T. Kritzberger. 1992. Ecological impacts of introduced animals in Nahuel Huapi National Park, Argentina. Conservation Biology 6:71-83.

Veblen, T.T., M. Mermoz, C. Martin, and E. Ramilo. 1989. Effects of exotic deer on forest regeneration and composition in northern Patagonia. Journal of Applied Ecology 26:711-724.

Vitousek, P.M., C.M. D’Antonio, L.L. Loope, M. Rejmánek, and R. Westbrooks. 1997. Introduced species: a significant component of Human-caused global change. New Zealand Journal of Ecology (1997) 21:1-16

Williamson, M. 1999. Invasions. Ecography 22:5-12.

Williamson, M., and A. Fitter. 1996. The varying success of invaders. Ecology 77:16611666. 